\title{
ADIÇÃO DE ÓLEO EM RAÇÕES COM DIFERENTES NIVEIS PROTÉICOS PARA COELHOS EM CRESCIMENTO
}

\author{
CYRO FERREIRA MEIRELLES
}

Orientador: Dr. Cyro Fúlvio Zinsly

Disserłação apresentada à Escola Superior de Agricultura "Luiz de Queiroz", da Universidade de São Paulo, para obłenção do Título de Mestre em Nutrição Animal e Pasłagens.

$P|R A C| C A B A$

Estado de São Paulo - Brasil

Outubro. 1978 
DED I C O:

A minha afetuosa esposa, Araci

e diletos filhos, Rodrigo,

Diogo e Gabriel. 


\section{AGRADECIMENTOS}

Ao Prof. Dr. Cyro fülvio Zinsly, amigo, mestre e orientador deste trabal ho.

A Rações Anhanguera da Duratex S.A. Indüstria e Comërcio, Campi nas, SP, representada pelo Prof. Dr. José Eduardo Bútolo, pelos ofereci mentos dos ingredientes das rações experimentais e resultados dos aminogramas.

A Organização Comercial Granja Selecta Ltda. - Itū - SP, pela doạ ção dos coelhos utilizados no presente ensaio.

Ao Prof. Dr. José Vicente Silveira Pedreira, Diretor do Instituto de Zootecnia - Nova Odessa, SP, pelas facilidades concedidas à realização do Curso de Pös-Graduação.

Ao Prof. Dr. Laērcio Melotti - Diretor de Divisão Técnica Bàsica e Auxiliar do Instituto de Zootecnia - Nova Odessa, SP, pelo apoio que nunca me foi regateado, deu-me alento para concluir o Curso de Pós-Graduação.

Ao Prof. Dr. Raul Dantas D'Arce, do Departamento de Zoologia, da Escola Superior de Agricultura "Luiz de Queiroz" - USP, Piracicaba-SP, pelo auxilio na versão do resumo para a lingua inglesa.

Ao Eng? Agr? Darcy Antonio Beisman, encarregado do Laboratörio de Bromatologia do Instituto de Zootecnia - Nova Odessa-SP, pelas determinaçōes das energias brutas das raçōes experimentais. 
iii.

Ao Prof. Dr. Irineu Humberto Packer, do Departamento de Zootecnia da ESALl, pelas sugestões dadas na feitura do delineamento experimental.

Aos Técnicos do Laboratörio de Bromatologia do Instituto de Zootecnia - Nova Odessa, SP, pelas anälises realizadas. 
1. RESUMO

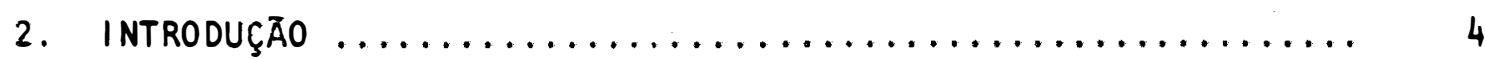

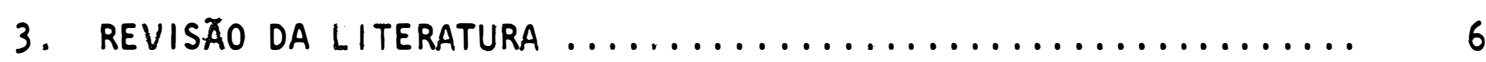

3.1. Exigências em proteína e aminoäcidos .............. 6

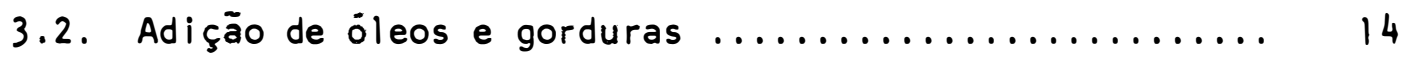

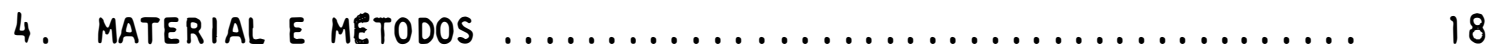

4.1. Generalidades $\ldots \ldots \ldots \ldots \ldots \ldots \ldots \ldots \ldots \ldots \ldots \ldots . \ldots \ldots$

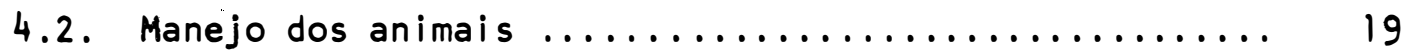

4.3. Delineamento experimental .................... 19

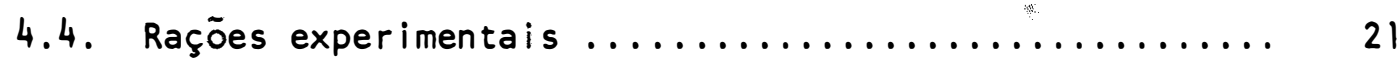

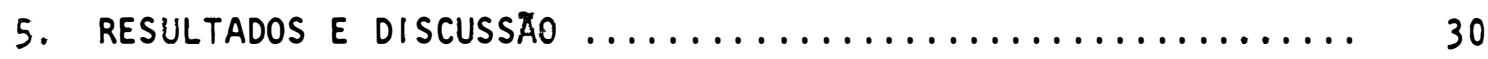

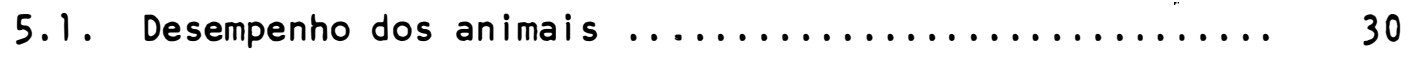

5.2. Efeito dos tratamentos sobre o ganho de peso total... 32

5.2.1. Efeito dos níveis de proteina e aminoäcidos... 33

5.2.2. Efeito da adição de öleo de soja .......... 36

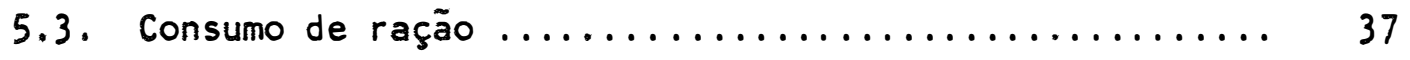

5.4. Conversão alimentar ....................... 40

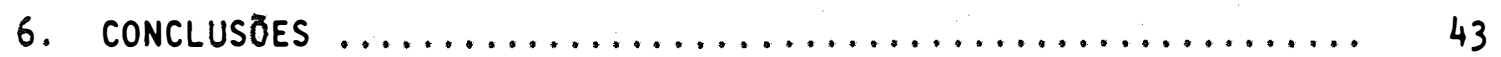

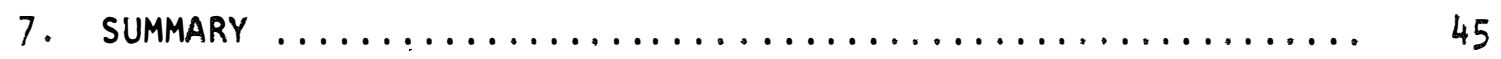

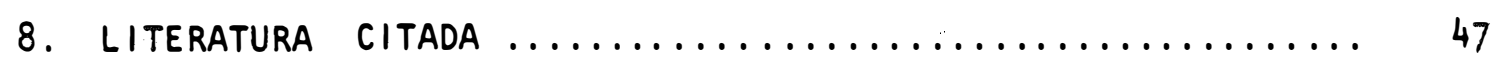

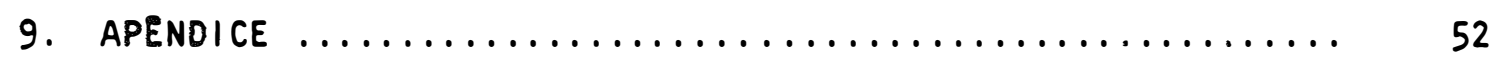




\section{LISTA DE TABELAS}

Pägina

Tabela 1 - Composição dos ingredientes das rações experimentais... 23

Tabela 2 - Percentagem dos aminoácidos nos ingredientes das rações experimentais ............................ 24

Tabela 3 - Composição percentual das rações experimentais no ni-

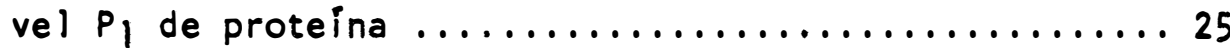

Tabela 4 - Composição percentual das rações experimentais no ni-

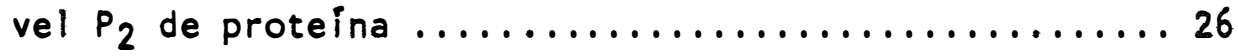

Tabela 5 - Teor em nutrientes das rações experimentais no nível $\mathrm{P}_{1}$

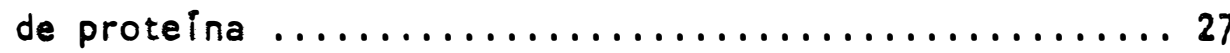

Tabela 6 - Teor de nutrientes das rações experimentais no nivel $P_{2}$

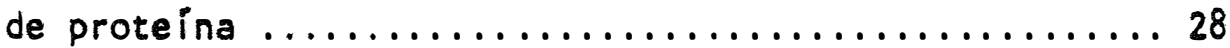

Tabela 7 - Composição do suplemento mineral e vitamínico e quantidade por quilograma de ração .................29

Tabela 8 - Pesos dos animais nos diversos tratamentos expressos em

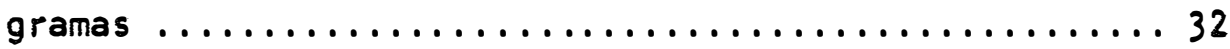

Tabela 9 - Efeitos dos tratamentos sobre o ganho de peso total por parcela expresso em gramas ..................... 33

Tabela 10-Anālise da variância do ganho de peso total.........34

Tabela 11- Efeito dos tratamentos sobre o ganho de peso diärio por cabeça expresso em gramas ..................... 34 
Tabela 12 - Efeito dos tratamentos sobre o consumo total de ração por parcela expresso em gramas ........... 38

Tabela 13 - Efeito dos tratamentos sobre o consumo diário de rạ ção por cabeça expresso em gramas ............. 38

Tabela 14 - Anālise da variância do consumo total de ração.... 39

Tabela 15 - Efeito dos tratamentos sobre a conversão alimentar. 41

Tabela 16 - Anälise da variância da conversão alimentar...... 42 
vii.

\section{LISTA DE FIGURAS}

Figura 1 - Curvas de Crescimento 
viii.

$A P E N D \perp C E$

Pägina

Tabela $A_{1}$ - Consumo total de ração expresso em gramas por parcela.. 53

Tabela $A_{2}$ - Ganho de peso total exprésso, em gramas, por parcela... 54

Tabela $A_{3}$ - Conversão alimentar, por parcela.............. 55

Tabela $\mathrm{A}_{4}$ - Coeficientes de digestibilidade das raçōes experimen -

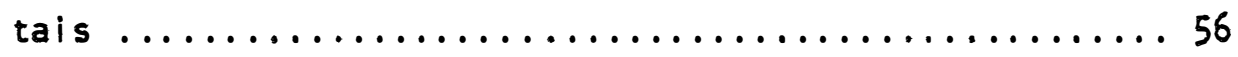


Nome: Cyro Ferreira Meirelles.

Data de Nascimento: 20 de agosto de 1939.

Local de Nascimento: Ribeirão Preto, SP, Brasil.

Formação Universitāria: Médico Veterinärio, formado em 1966, pela Faculdade de Medicina Veterinäria e Zootecnia - Universidade de São Paulo - São Paulo, SP, Brasil.

Atividade Atual: Auxiliar de Ensino - Disciplina de Anatomia e Fisiologia Animal na Escola Superior de Agricultura "Luiz de Queiroz" - Universidade de São Paulo Piracicaba, SP, Brasil. 


\section{RESUMO}

Noventa e seis coelhos de ambos os sexos com trinta dias de idade, mestiços entre as raças Nova Zelāndia Branca e California, foram mantidos aos pares em gaiolas por quarenta e nove dias e alimentados a vontade com rações em dois níveis de proteina $P_{1}=15 \%$ e $P_{2}=18 \%$ e três níveis de ōleo de soja $0=0 \%, 0_{1}=3 \%$ e $0_{2}=6 \%$, com o objetivo de se estudar os efeitos das combinações dos diferentes niveis de ōleo e proteina sobre o crescimento.

As rações com $15 \%$ de proteina continham $0,62 \%$ de lisina, $0,65 \%$ de metionina + cistina e $0,84 \%$ de arginina, enquanto que as rações com $18 \%$ de proteina apresentavam $0,82 \%$ de 1 isina, $0,78 \%$ de metionina + cistina e $1,08 \%$ de arginina.

o delineamento experimental utilizado foi o de blocos casualizados, com esquema fatorial $2 \times 2 \times 3$ em que se estudaram os efeitos do sexo, proteina e óleo de soja. 
A anālise da variância para ganho de peso total, conversão alimentar e consumo total de ração, revelaram que não houve efeitos significativos $(P<0,05)$ para sexos, proteina, niveis de óleo e possiveis interações.

0 presente ensaio possibilitou as seguintes conclusões:

1 - A exigência protēica de coelhos em crescimento pode ser satisfeita com o fornecimento de ração contendo $15 \%$ de proteĩna bruta.

2 - Os niveis de metionina + cistina e arginina devem estar situados ao redor de 0,65 e $0,84 \%$ da ração com aquele teor protéico.

3 - Embora o nível de $0,62 \%$ de lisina nas rações para coelhos em crescimento, com $15 \%$ de prote na bruta tenha sido adequado, supõe-se que deva ser mais elevado.

4 - Observou-se que a inclusão de óleo de soja, em rações para coelhos em crescimento, com 15\% e $18 \%$ de proteina bruta, não proporcionou um maior ganho de peso e melhoria na conversão ali mentar. 
5 - 0 aumento do nỉvel energético das rações atravēs da inclusão do óleo de soja, não alterou o consumo, motivado talvez pela saponificação. que ocorre no trato intestinal. 


\section{INTRODUÇAOO}

A cunicultura nacional, apesar da expansão que vem sofrendo nestes ūltimos anos, ressente-se no campo da nutrição, em virtude do pequeno nümero de trabalhos efetuados em nosso meio. Assim torna-se comum na prätica a formulação de rações ünicas, tanto para as fases de crescimento, como para as de reprodução, manutenção e aleitamento, refletindo negativamente na produção e no custo. Pensando-se no alto preço dos suplementos protēicos, hā que se preocupar em usar um nüme ro minimo de proteinas e para tanto necessita-se estabelecer as exigências dos aminoácidos 1 imitantes para coelhos, que servirão de enriquecị mento das rações obtendo-se formulações com menores despesas. Apoiandose em todos estes fatos, é que foi elaborado o presente ensaio, tendo como objetivo estabelecer uma ração para coelhos em crescimento, estu dando-se os efeitos de dois níveis protēicos, associados à adição de óleo de soja em teores crescentes. O grande espaçamento dado aos niveis protéicos de 15 e $18 \%$ foi instituído pelo fato de haver enormes disparị 
dades entre os estudiosos como MAZZIOTTI et alii (1976) que empregaran uma ração com 12,40\%, enquanto DAVIDSON e SPREADBURY (1973) com 15\%, COLIN (1974) com 17\%, RAIMONDI e AUXILIA (1974) com 19,90\%, MARTINA (1975) com 19,31\%. Por outro lado a inclusão do óleo de soja, teve o fito de verificar se com os coelhos ocorre o mesmo fenōmeno observado em aves, em que rações com altos nîveis de gordura apresentam uma melhoria no crescimento e na conversão alimentar. As rações foram formuladas, apresentando teores iguais e elevados de fibra, sendo que a inclusão do óleo de soja foi também a única maneira de se conseguir uma diferença nos niveis de energia bruta. 0 trabalho tambēm teve a finalidade de verifi car se nas condições experimentais os teores dos aminoācidos lisina, metionina + cistina e arginina eram adequados. 


\section{REVISAOO DA LITERATURA}

\subsection{Exigências em proteina e aminoācidos}

Pelo trabaino de revisão de AITKEN e WILSON (1962), sabe-se que as primeiras informações acerca da exigência protêica de coeIhos, surgiu no ano de 1933. Esses trabalhos, entretanto, não puderam ser consultados no original e as informações fornecidas pelos autores anteriormente citados não bastaram para uma interpretação adequada dos resultados.

Pelos motivos expostos, esta revisão bibliográfica se inicia com a informação do NATIONAL RESEARCH COUNCIL (NRC) (1954), 0 qual recomenda para coelhos de 1,800 a $3,200 \mathrm{~kg}$ de peso vivo, ração com nỉvel de $16 \%$ de proteina digestivel, para um ganho diārio de $34 \mathrm{~kg}$ por cabeça e por dia.

Posteriormente SMITH et alii (1960) in AITKEN e WILSON (1962) comprovaram ser a exigēncia protéica de coelhos em crescimento 
menores que as citadas pelo NRC (1954). Esses autores forneceram raçoes que continham de 12 a $19 \%$ em proteina bruta, para coelhos pesando de 1,350 a $2,700 \mathrm{~kg}$ e concluiram serem os nîveis de 13 e $14 \%$ os que melhores resultados apresentaram em termos de ganho de peso e conversão alimentar.

Na bibliografia consultada a primeira referēncia sobre - estudo da exigéncia em aminoācidos para coelho é de CASADY et alii (1961), os quais se utilizaram de uma ração padrão que continha $40 \%$ de feno de alfafa, $18 \%$ de farelo de soja, além de cevada, aveia, ōleo de linhaça e suplementação com 0,$1 ; 0,2$ e $0,4 \%$ de lisina e metionina. As rações foram fornecidas para coelhas em gestação e posteriormente aos filhotes. Para todos os tratamentos houve um aumento significativo nos ganhos de peso, sem contudo proporcionar melhora na conversão alimentar.

Apesar dos resultados anteriormente citados, 0 NRC (1966) relata ser a sensibilidade do coelho para a qualidade da proteina, ainda desconhecida, mas sugere que esta qualidade pode não de grande importāncia, em virtude dos coelhos serem criados com sucesso, mesmo quando alimentados, apenas com produtos e subprodutos de origem vegetal e recomenda os níveis de 15 a $16 \%$ de proteĩna bruta na ração, para ganho diārio de $32 \mathrm{~g}$.

MACWARD et alii (1967) usando rações purificadas conten do caseina como fonte protéica, concluíram que a arginina para coelhos em crescimento é requerida na proporção de 0,98 a $1,23 \%$ na dieta. 
A comprovação da sensibilidade de coethos em crescimento para a qualidade cia proteina tambēm foi demonstrada por CHEEKE (1971), fornecendo raçöes identicas, com exceção de fonte protéica. As sim, enquanto a caseina proporcionou crescimento normal, a gelatina e a zeina reduziram 0 ganho de peso e o consumo, os quais foram atribui dos à ceficiência de alguns aminoácidos na ração. A seguir, o autor efetuou cinco ensaios com a finalidade de estabelecer os niveis ótimos de lisina, metionina e arginina. As rações empregadas eram compostas dos seguintes ingredientes: feno de alfafa, cevada, milho, farelos de soja e algodão. Foi sugerido para coelhos em crescimento, $0,88 \%$ de argi nina, $0,93 \%$ de 1 isina e $0,45 \%$ de metionina.

CHEEKE e AMBERG (1972) se utilizaram de rações com 15\% de proteina, nas quais as fontes protéicas foram farelo de soja, farelo de algodão e farinha de peixe. As rações continham teores calculados de lisina $(0,613 ; 0,495$ e $0,831 \%)$, arginina $(0,784 ; 0,974$ e $0,71 \%)$ e metionina $(0,202 ; 0,238$ e $0,285 \%)$, respectivamente. 0 farelo de algo dào proporcionou menor ganho diārio de peso (25 g) comparativamente ao fareio de soja $(35 \mathrm{~g})$ e a farinha de peixe $(34 \mathrm{~g})$. Em ensaio posterior os autores empregaram as mesmas raçōes mas adicionadas de quantidades variāveis dos aminoácidos citados, as quais proporcionaram, respectivamente, para as rações contendo farelo de soja, farelo de algodão e farinha de peixe: 0,$953 ; 0,945$ e $1,073 \%$ de lisina, 0,$904 ; 0,974$ e $0,950 \%$ de arginina, 0,$452 ; 0,448$ e $0,445 \%$ de metionina. Neste caso os ganhos diários de peso foram: $37 \mathrm{~g}$ para o fareio de soja, $35 \mathrm{~g} \mathrm{pa-}$ ra 0 farelo de algodão e $39 \mathrm{~g}$ para a farinha de peixe. 
ADAMSON e FISHER (1973) trabalhando com ração purificada, realizaram uma série muito grande de ensaios através dos quais determinaram os niveis adequados para cada um dos dez aminoācidos essenciais. Com base nos resultados obtidos recomendaram os seguintes niveis de aminoácidos em percentagem da ração: arginina $(1,0)$, histidina $(0,45)$, metionina + cistina $(0,60)$, treonina $(0,50)$, triptofano $(0,15)$, leucina $(0,90)$, valina $(0,70)$, isoleucina $(0,70)$, lisina $(0,70)$ e fenilalanina $(0,60)$.

DAVIDSON e SPREADBURY (1973) utilizaram coelhos de quatro a oito semanas de idade, os quais alimentaram com ração apresentando $15 \%$ de proteina e composta de cereais, feno de alfafa, farinha de peixe, minerais e vitaminas, a qual proporcionou ganho diārio de $40 \mathrm{~g}$. A percentagem em aminoācidos era: arginina $(0,70)$, glicina $(0,50)$, histidina $(0,30)$, leucina $(1,10)$, metionina + cistina $(0,55)$, fenilalanina + tirosina $(1,1)$, treonina $(0,60)$, triptofano $(0,20)$, valina $(0,70)$, is $\underline{0}$ leucina $(0,60)$ e lisina $(0,90)$.

Empregando rações semipurificadas que continham 13, 17 e $21 \%$ de proteina e cuja fonte protēica era o farelo de gergelim COLIN, (1974) demonstrou que a adição de lisina foi eficaz apenas para a ração com $17 \%$ de proteina, visto que a ração com $13 \%$ de proteỉna, proporcionou ganhos mediocres e os resultados obtidos com a ração de $21 \%$ se iguala rem aos da ração com $17 \%$. 0 autor concluiu ser $17 \%$ de proteina e 0,65 de lisina os niveis mais recomendäveis para coelhos em crescimento. 
Em outro trabalho, COLIN (1975) utilizou uma ração com $16,80 \%$ de proteina, a qual era composta de farelo de trigo, farelo de gi rassol e feno de alfafa. Continha $2.250 \mathrm{Kcal} / \mathrm{kg}$ de energia digestivel, $0,52 \%$ de aminoācidos sulfurados e $0,58 \%$ de lisina, e foi suplementada com $0,10 \%$ de 1 isina e $0,20 \%$ de metionina. Os resultados mostraram que a adição dos aminoācidos acima citados não melhorou o desenvolvimento dos animais e que a metionina provocou um menor crescimento e diminuiu o con sumo. Num segundo experimento, o mesmo autor utilizou ração à base de fe no de alfafa, farelo de soja, farelo de girassol e amido de milho a qual continha $2.660 \mathrm{Kcal} / \mathrm{kg}$ de energia digestivel, $16 \%$ de proteinna bruta,0,71\% de lisina e $0,43 \%$ de aminoācidos sulfurados. A ração foi suplementada com $0,10,0,20$ e $0,30 \%$ de DL-metionina e o pesquisador relatou ter obtido o ganho de peso diārio mais elevado $(37,6 \mathrm{~g})$ com a ração contendo $0,63 \%$ de aminoācidos sulfurados. Por outro lado, COLIN (1976a) trabalhando com coelhos de 35 a 42 dias de idade e utilizando rações, cujas fontes proteicas eram: farelo de girassol ou farelo de gergelim ou farelo de soja, mostrou que as rações deveriam conter $0,90 \%$ de arginina, independente da taxa de lisina. 0 autor confirmou que hā necessidade da cistina + metionina aparecerem na ração na proporção de 0,60 a $0,65 \%$.

Coelhos de ambos os sexos com 35 dias de vida (MAZZIOTTI et alii, 1976) foram sorteados ao acaso e distribuídos em trēs tratamentos e alimentados com ração basal contendo $12,4 \%$ de proteina, cuja fonte proteica era 0 farelo de girassol. A esta ração foram adicionadas $0,20 \%$ de metionina $+0,30 \%$ de lisina ou $0,40 \%$ de metionina $+0,60$ de lisina. 
As rações apresentaram em relação à matéria seca $0,45 \%$ de 1 isina e $0,54 \%$ de metionina + cistina; $0,74 \%$ de lisina e $0,73 \%$ de metionina + cistina e $1,03 \%$ de lisina e $0,92 \%$ de metionina + cistina, respectivamente. Os animais foram pesados semanalmente e abatidos aos 77 dias de idade. Os ganhos de peso diārio foram para a ração basal de $20,20 \mathrm{~g}$ e para as suplementadas $24,10 \mathrm{~g}$ e $27,30 \mathrm{~g}$, respectivamente. As rações suplementadas melhoraram o crescimento na proporção de 19,31 e 35,15\%, sendo a conversão alimentar não influenciada com o incremento dos aminoācidos sintéti$\cos$.

Em condições especiais a metionina pode ser fornecida na água de bebida (COLIN, 1976b). O autor recomenda a adição de $1,5 \mathrm{~g}$ de metionina por litro de āgua, renovada todos os dias e para rações com menos de $0,44 \%$ de aminoācidos sulfurados.

A uma ração basal que continha farelo de girassol como fonte protéica e encerrava $15,09 \%$ de proteína e $3.776 \mathrm{Kcal} / \mathrm{kg}$ de energia bruta (COLIN, 1973), adicionou niveis crescentes de lisina e obteve rações que continham 0,$33 ; 0,56 ; 0,78 ; 1,00$ e $1,23 \%$ do aminoácido. Fornecendo a coelhos com cinco semanas de idade, verificou que a ração contendo $0,78 \%$ de lisina proporcionou um melhor ganho de peso diārio que foi de $40,70 \mathrm{~g}$.

LEBAS (1973) trabalhando com rações cuja ūnica fonte protéica era o farelo de soja ou farelo de gergelim, concluiu ser o nivel de $17 \%$ de proteỉna bruta o mais indicado. Com relação aos aminoāci dos recomendou $0,45 \%$ de metionina, $0,54 \%$ de 1 isina e $0,90 \%$ de arginina. 
Com esses nîveis obteve ganho diārio de $34 \mathrm{~g}$ e indice de conversão $1: 3,5$.

RAIMONDI e AUXILIA (1974) estudaram o efeito do nível protéico constante ou variāvel sobre o desempenho de coelhos para corte. Um tratamento consistiu em se fornecer ração com 17,60\% de proteina, da desmama ao abate e outro em se fornecer ração com 19,90\% de proteĩna da desmama aos 56 dias de idade e ração com $17,60 \%$ de proteĩna dos 56 dias ao abate. A pesquisa evidenciou que a conversão alimentar para o trata mento com $17,60 \%$ de proteina foi de 2,96 e para o outro foi de 3,04 . Os ganhos de peso diārio para o nível fixo de proteina foi de $39 \mathrm{~g}$ enquanto que para o variāvel foi de $38 \mathrm{~g}$.

CHEEKE (1974) avaliou um concentrado de proteina de alfafa, formulando rações com $17 \%$ de proteina, nas quais o referido concen trado entrou em proporções variāveis, de modo a substituir de zero a $100 \%$ a proteỉna da ração, oriunda do farelo de soja. 0 autor obteve 0 maior ganho de peso diārio $(37,2 \mathrm{~g})$ e o melhor indice de conversão ( 1: $2,94)$ quando o concentrado de proteīna de alfafa contribuiu com $25 \%$ da proteina total da ração. A concentração em aminoācidos da ração mais eficiente, atingiu o nível de $0,93 \%$ de lisina, $0,58 \%$ de metionina + cis tina e $1,06 \%$ de arginina.

Tendo em vista a composição de uma única ração para coeIhos em crescimento, MARTINA (1975) comparou quatro formulações contendo em diferentes proporções os mesmos ingredientes. A primeira oferecida en tre 35 a 60 dias de idade, possuindo 19,31\% em proteina bruta, $2.795 \mathrm{Kcal} /$ 
kg de energia metabolizāvel e $6,50 \%$ de fibra bruta, a seguir, substituỉda por outra dos 61 aos 90 dias, apresentando $16,62 \%$ em proteina bruta 2.541 $\mathrm{Kcal} / \mathrm{kg}$ de energia metabolizável e $9,39 \%$ de fibra bruta. A terceira foi ministrada dos 35 aos 90 dias de vida fornecendo 19,05\% de proteỉna bruta, $2.694 \mathrm{Kcal} / \mathrm{kg}$ de energia metabolizável e $7,9 \%$ de fibra bruta. A quar ta continha $16,6 \%$ em proteina bruta, $2.661 \mathrm{Kcal} / \mathrm{kg}$ de energia metabolizâa vel e $8,10 \%$ de fibra bruta, sendo oferecido dos 35 aos 90 dias de vida. os resultados obtidos mostraram que o desempenho dos animais, medidos em termos de ganho de peso, foram iguais para os três tratamentos sendo indicada a utilização da quarta formulação, por apresentar um menor custo e peso médio de $2,192 \mathrm{~kg}$ aos 90 dias.

COLIN et alii (1973) utilizaram-se de ração semi-purificada, cuja fonte protéica era o farelo de soja e apresentava os seguintes niveis de nutrientes: $17 \%$ de proteina, $3.900 \mathrm{Kcal} / \mathrm{kg}$ de energia bruta e $0,46 \%$ de metionina + cistina. A esta ração adicionaram nîveis crescentes $(0,20-0,40-0,80$ e $1,60 \%)$ de metionina e forneceram as cinco rações para coelhos com quatro semanas de idade, durante seis semanas. Os resultados obtidos com as rações adicionadas de 0,$20 ; 0,40$ e $0,80 \%$ de metionina, não apresentaram diferenças significativas, sendo que para a ração com a adição de $0,20 \%$ o ganho diārio foi de $30,60 \mathrm{~g}$ e a conversão alimentar de $1: 2,51$. Com a adição de $1,6 \%$ de metionina, houve uma depres são no ganho de peso diārio $(21,30 \mathrm{~g})$ sem alterar a conversão alimentar $(1: 2,45)$.

MARTINA (1976) trabalhando com coelhos Nova Zelândia des mamados aos 34 dias de idade, mostrou ser viāvel a substituição total 
do leite em pó desnatado utilizado na proporção de $3 \%$ da ração, por fare 10 de girassol. O nîvel energético da ração era de $2.565 \mathrm{Kcal}$ de energia metabolizável por $\mathrm{kg}$ de alimento e de $17,11 \%$ de proteina. Os animais aos 87 dias de idade apresentavam em mëdia $2.270 \mathrm{~kg}$ de peso vivo e ganho diārio de $28,81 \mathrm{~g}$.

\subsection{Adiçāo de óleos e gorduras.}

Coelhos com quatro semanas de idade, recebendo rações pu rificadas ad libitum, revelaram maior crescimento e pior indice de conversão, quando consumiram dietas contendo $10 ; 15 ; 20$ e $25 \%$ de óleo vegetal hidrogenado ao invēs de consumirem ração com $5 \%$ de ōleo ou sem adição (THACKER, 1956). A piora na conversão foi resultante do maior consumo.

Com a finalidade de estudar o efeito da gordura na utili zação da energia e proteĩna, TELEKI e DARWISH (1970) trabalharam com três lotes de coelhos em crescimento. Um deles recebeu uma ração contendo: milho: $40 \%$; cevada: $20 \%$, enquanto que os outros dois tiveram igual tratamento com a adição de 3 a $6 \%$ de gordura. Embora a adição de gordura tenha resultado ligeiro aumento no teor de energia das fezes, o balanço total revelou melhor aproveitamento da energia da ração, equivalência quanto à proteīna, decréscimo na digestibilidade da matéria seca e da fibra e redução no quociente respiratório.

Três ensaios de digestibilidade utilizando-se coelhos pe sando inicialmente $2,5 \mathrm{~kg}$ foram efetuados por ARAGON et alii. (1971), os 
quais se utilizaram de ração com $3,1 \%$ de matéria graxa à qual foi adicio nado óleo de oliva, formando-se as outras duas rações, contendo: 6,4 e $9,7^{\circ}$, de extrato etéreo. A digestibilidade da matéria seca e da matéria orgānica aumentou com a elevação do teor de gordura. Com relação à digestibilidade da proteỉna e fibra não houve diferença significativa, enquanto que para os extrativos não nitrogenados aumentou com o acréscimo do nivel de gordura. Decréscimo na digestibilidade da gordura foi observado quando a taxa deste nutriente era de $9,7 \%$.

CHIERICATO e LANARI (1972) verificaram os efeitos da adi ção de sebo bovino à ração de coelhos em crescimento com 50 dias de idade. A adição de $5 \%$ provocou redução no consumo de alimento, melhora na conversão, não alterando entretanto o crescimento. A adição de $10 \%$, por outro lado, fêz decrescer o consumo e o ganho de peso e não alterou a conversão.

ARRINGTON et alii (1974) trabalharam com coelhos desmama dos de seis a sete semanas de idade, os quais alimentaram com rações semi-purificadas, contendo feno de grama bermuda, farelo de soja, sacaro se e amido. Atravēs da adição de óleo de milho obtiveram rações com $2,40-6,40-8,20-10,20$ e $14,40 \%$ de extrato etéreo, os quais tiveram diferentes efeitos sobre o desempenho dos animais. Assim os autores relataram terem observado redução no consumo com o aumento de óleo e diferença significativa no ganho de peso somente comparando-se os teores de 2,40 e 14,40\%. 0 indice de conversão melhorou com 0 aumento do teor de óleo e a quantidade de proteina por unidade de ganho de peso diminuiu até o nîvel de $8,20 \%$ de óleo. 
Coelhos em crescimento foram alimentados com trēs tipos de rações isoproteicas $(19 \%)$, com igual teor de fibra (14\%) e com diferentes nỉveis energéticos: $4.377,4.623$ e $4.862 \mathrm{Kcal} / \mathrm{kg}$ na matéria seca, sendo a fonte energética o sebo bovino nas proporções de 0,5 e $10 \%$. Nenhuma diferença significativa foi •bservada com relação à digestibili dade da matéria seca, proteina e energia (PARIGI-BINI et alii, 1974). Os autores concluĩram que esses resultados foram devidos ao não aprovei tamento do sebo adicionado em virtude da saponificação que ocorre no trato intestinal, a qual é responsável pelo menor aproveitamento dos 1 i pideos adicionados, dando como resultado final menor quantidade de ener gia digestiva.

Ofereceram-se a coelhos em crescimento (LEBAS, 1975), ra ções semi-purificadas isoprotéicas (18\% de proteĩna) formuladas à base de farelo de gergelim e amido de milho. Verificou-se que o aumento do extrato etéreo de 4,5 para 8,5 ou $12,5 \%$ na ração, não modificou a con versão alimentar e a quantidade de alimento consumido. 0 aumento da taxa de lipídeos não modificou o teor de energia digestîvel da ração empregada, em consequência da baixa utilização dos lipîdeos acrescentados.

Uma carēncia de àcidos graxos essenciais em coelhos foi verificada por AHLUWALIA et alii (1967) com o emprego de ração semi-purificada, com e sem adição de lipỉdeos. Durante um período de dez semanas, os animais controle tiveram um ganho de $18 \mathrm{~g}$ de peso por $100 \mathrm{~g}$ de ração, enquanto que os deficientes ganharam $10 \mathrm{~g}$ por $100 \mathrm{~g}$ de ração. Não houve diferença quanto ao consumoalímentar para os dois grupos. 
RAIMONDI et alii (1973) empregaram 64 coelhos, desmamados aos 28 dias de idade e divididos em oito tratamentos, a fim de verifi carem a influência do nỉvel energético $(1.600 \mathrm{a} 1.800 \mathrm{Kcal} / \mathrm{kg}$ de energia liquida estimada) e do conteúdo protēico (17 e 20\%) da ração, sobre 0 crescimento, consumo e conversão alimentar. As rações continham: farelo de milho, feno de alfafa, farelo de girassol, farelo de soja, cevada integral além de rolão de trigo, carbonato bicālcico, fosfato bicálcico, complexo mineral e vitaminico. Duas rações com 17 e $20 \%$ de proteina continham a inda $3,50 \%$ de ōleo vegetal, As rações com 17 e $20 \%$ de proteina, adicionadas de ōleo proporcionaram aos animais um crescimento reduzido sem influir no consumo. A melhor utilização protéica ocorreu com baixo nível energético. Até aos 56 dias de idade o efeito do óleo foi negativo, dos 56 aos 91 dias o óleo melhorou a conversão, o crescimento e o consumo alimentar. Dos 28 aos 56 dias as rações com maior nível protéico tiveram uma melhor utilização alimentar. 


\section{MATERIAL E MÉTODOS}

\subsection{Generalidades}

0 ensaio foi realizado nas dependências do Setor de Cunicultura do Departamento de Zootecnia da Escola Superior de Agricultura "Luiz de Queiroz".

Utilizaram-se 96 coelhos, procedentes da Organização comercial Granja Selecta Ltda, em Itū, Estado de São Paulo, sendo 48 machos e 48 fêmeas, mestiços entre as raças Nova Zelândia Branca e Califōr nia, desmamados aos vinte e oito dias de idade.

0 galpão experimental possuĩa paredes frontais com $2 \mathrm{~m}$ de altura e abertura superior para ventilação de $1 \mathrm{~m}$ e lateralmente era fechado com tela metālica tendo muretas de proteção de $0,5 \mathrm{~m}$ de altura.

Os láparos foram alojados aos pares, em gaiolas metāilicas com $40 \mathrm{~cm}$ de largura, $38 \mathrm{~cm}$ de altura e $60 \mathrm{~cm}$ de profundidade dis- 
postas em dois andares, possuindo entre eles bandeja inclinada para cole ta de fezes e urina.

Cada gaiola dispunha do comedouro e bebedouro automáti $\cos$.

\subsection{Manejo dos animais.}

Para escolha dos animais utilizados no experimento, foram considerados idade das mães, nümero de animais da ninhada, peso médio da ninhada e eliminação de animais com pesos extremos. Por ocasião da chegada, os mesmos foram pesados e identificados atravēs de tatuagem na orelha, sendo este peso o considerado para a formação dos blocos.

Na primeira semana do ensaio, ocorreu nos animais uma diarréia inespecífica, sendo controlada com sulfadimetoxina sódica na àgua de bebida, durante sete dias na dosagem de $0,05 \%$.

Os coeThos foram pesados individualmente uma vez por semana. O consumo de ração foi controlado para cada dois animais, atravēs da diferença entre as quantidades distribuídas e as sobras.

\subsection{Delineamento experimental.}

Utilizou-se um delineamento experimental em blocos casua lizados com esquema fatorial $2 \times 2 \times 3$, para estudar os efeitos do sexo, niveis de proteina e de öleo de soja sobre o crescimento. 
Os tratamentos tiveram quatro repetiçães de dois animais, portanto a unidade experimental era representada por uma gaiola.

Com 0 intüito de se evitar as eventuais variações no ambiente, os blocos foram compostos por fileiras de gaiolas dispostas no sentido longi zudinal.

Os tratamentos foram os seguintes:

$P_{Y} 0=$ Ração com $15 \%$ de proteĩna sem adição de ōleo.

$\mathrm{P}_{1} \mathrm{O}_{1}=$ Ração com $15 \%$ de proteỉna e adição de $3 \%$ de 00 leo.

$\mathrm{P}_{1} \mathrm{O}_{2}=$ Ração com $15 \%$ de proteina e adição de $6 \%$ de 0 leo.

$\mathrm{P}_{2} \mathrm{O}=$ Ração com $18 \%$ de proteĩna sem adição de ōleo.

$\mathrm{P}_{2} \mathrm{O}_{1}=$ Ração com $18 \%$ de proteĩna e adição de $3 \%$ de 0 leo.

$\mathrm{P}_{2} \mathrm{O}_{2}=$ Ração com $18 \%$ de proteĩna e adição de $6 \%$ de 0 leo.

As anālises estatîsticos dos dados encontrados foram baseados nos trabalhos de SNEDCOR e COCHRAM (1975).

Utilizou-se o seguinte esquema de anālise da variāncia:

Fontes de variação.

Graus de liberdades

Sexo (S)

Proteina (P)

oleo (0)

$S \times P$

$S \times 0$

$P \times 0$

$S \times P \times 0$

Tratamentos

Blocos

Resíduo

1

Total 
A coleta de dados iniciou-se no dia 17 de outubro de 1977 e terminou em 5 de dezembro do mesmo ano, tendo uma duração de 49 dias.

Ao término do ensaio os animais estavam com 79 dias de

vida.

$\mathrm{Na}$ avaljação dos objetivos do trabalho foram considerados: ganho de peso total, conversão alimentar e consumo total de ração.

Para melhor acompanhar os efeitos dos tratamentos, fêzse paralelamente um ensaio de digestibilidade. Utilizaram-se 12 coelhos sendo seis machos e seis fêmeas. O nümero de repetições por tratamento foi de dois animais de sexos diferentes.

Os resultados são apresentados na Tabela $\mathrm{A}_{4}$ no Apêndice.

\subsection{Rações experimentais}

As rações experimentais foram preparadas a partir de ingredientes fornecidos pela Rações Anhanguera, Campinas, SP e analisados nos laboratórios de bromatologia do Instituto de Zootecnia em Nova Odessa, SP, segundo métodos preconizados pela "Association of Official Agricultural Chemists" (A.O.A.C., 1965). Os resultados das anālises são mostrados na Tabela 1.

0 Laboratōrio de Controle de Qualidade da Rações Anhanguera, Campinas, SP, forneceu aminograma completo dos ingredientes, obtido de 
22.

amostras das partidas dos quais os referidos ingredientes foram retirados. Os dados são fornecidos na Tabela 2.

As rações foram preparadas e granuladas nas dependências do Instituto de Zootecnia, em Nova Odessa, SP tendo os grānulos $5 \mathrm{~mm}$ de diāmetro e $10 \mathrm{~mm}$ de comprimento.

Nas Tabelas 3 e 4 é dada a composição percentual das rações experimentais e nas Tabelas 5 e 6 os teores dos nutrientes. 


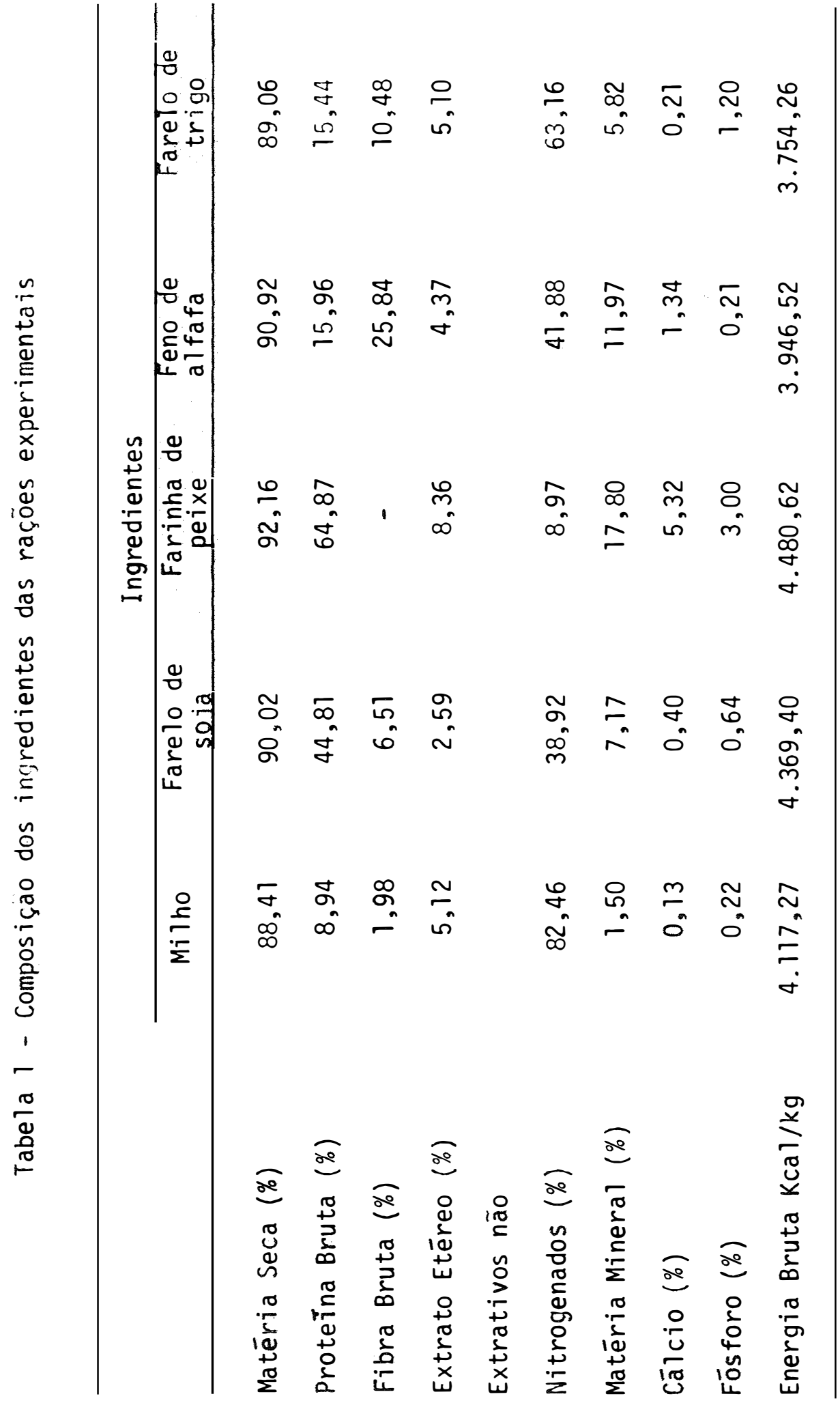


Tabela 2 - Percentagem dos aminoācidos nos ingredientes das rações experimentais

\begin{tabular}{|c|c|c|c|c|c|}
\hline \multirow[b]{2}{*}{ Aminoācidos } & \multicolumn{5}{|c|}{ Ingredientes } \\
\hline & $\underset{\text { peixe }}{\text { Farinha de }}$ & Milho & $\begin{array}{c}\text { Farelo de } \\
\text { soja }\end{array}$ & $\begin{array}{l}\text { Feno de } \\
\text { alfafa }\end{array}$ & $\begin{array}{c}\text { Farelo de } \\
\text { trigo }\end{array}$ \\
\hline Alanina & 4,08 & 0,67 & 1,94 & 0,72 & 0,73 \\
\hline Arginina & 3,76 & 0,47 & 3,24 & 0,58 & 0,11 \\
\hline Ac. aspārtico & 6,23 & 0,69 & 5,53 & 1,25 & 1,20 \\
\hline Cistina & 0,60 & 0,19 & 0,84 & 0,15 & 0,35 \\
\hline Fenilalanina & 2,43 & 0,46 & 2,28 & 0,65 & 0,60 \\
\hline Glicina & 5,26 & 0,40 & 1,97 & 0,70 & 0,82 \\
\hline Ac. glutāmico & 8,07 & 1,86 & 7,73 & 1,49 & 2,75 \\
\hline Histidina & 1,77 & 0,28 & 1,02 & 0,26 & 0,44 \\
\hline Isoleucina & 2,52 & 0,34 & 2,06 & 0,62 & 0,48 \\
\hline Leucina & 4,43 & 1,09 & 3,39 & 1,05 & 0,92 \\
\hline Lisina & 4,72 & 0,31 & 2,64 & 0,40 & 0,63 \\
\hline Metionina & 1,64 & 0,14 & 0,61 & 0,19 & 0,22 \\
\hline Prolina & 3,36 & 0,83 & 1,93 & 0,60 & 0,88 \\
\hline Serina & 2,48 & 0,46 & 2,32 & 0,65 & 0,64 \\
\hline Tirosina & 2,36 & 0,22 & 1,30 & 0,41 & 0,54 \\
\hline Treonina & 2,53 & 0,34 & 1,73 & 0,57 & 0,50 \\
\hline Triptofano & 0,89 & 0,09 & 0,57 & 0,20 & 0,24 \\
\hline Valina & 3,14 & 0,55 & 2,17 & 0,85 & 0,73 \\
\hline
\end{tabular}


Tabela 3 - Composição percentual das rações experimentais no nivel $P_{7}$ de proteina

\begin{tabular}{lccc}
\hline & \multicolumn{3}{c}{ Tratamentos } \\
\cline { 2 - 4 } Ingredientes & $P_{10}$ & $P_{1} 0_{1}$ & $P_{102}$ \\
\hline Milho & 42,000 & 41,000 & 40,000 \\
Farelo de Soja & 6,000 & 7,000 & 8,000 \\
Farinha de Peixe & 2,000 & 2,000 & 2,000 \\
Feno de Alfafa & 26,000 & 26,000 & 26,000 \\
Farelo de Trigo & 21,000 & 18,000 & 15,000 \\
Oleo de Soja & - & 3,000 & 6,000 \\
Bentonita & 1,155 & 1,150 & 1,144 \\
Sal & 0,500 & 0,500 & 0,500 \\
Farinha de Ossos & 1,000 & 1,000 & 1,000 \\
Metionina & 0,172 & 0,177 & 0,183 \\
Complexo Mineral & 0,173 & 0,173 & 0,173 \\
e Vitaminico* & 10000 & 100,000 & 100,000 \\
\hline Total & & & \\
\hline
\end{tabular}

¿ Composição dada na Tabela 7. 
Tabela 4 - Composição percentual das rações experimentais no nível $P_{2}$ de proteina

\begin{tabular}{|c|c|c|c|}
\hline \multirow{2}{*}{ Ingredientes } & \multicolumn{3}{|c|}{ Tratamentos } \\
\hline & $P_{2} 0$ & $\mathrm{P}_{2} \mathrm{O}_{1}$ & $\mathrm{P}_{2} \mathrm{O}_{2}$ \\
\hline Milho & 35,000 & 34,000 & 33,000 \\
\hline Farelo de Soja & 15,000 & 16,000 & 17,000 \\
\hline Farinha de Peixe & 2,000 & 2,000 & 2,000 \\
\hline Feno de Alfafa & 25,000 & 25,000 & 25,000 \\
\hline Farelo de Trigo & 20,000 & 17,000 & 14,000 \\
\hline Oleo de Soja & - & 3,000 & 6,000 \\
\hline Bentonita & 1,124 & 1,118 & 1,112 \\
\hline Sal & 0,500 & 0,500 & 0,500 \\
\hline Farinha de Ossos & 1,000 & 1,000 & 1,000 \\
\hline Metionina & 0,203 & 0,209 & 0,215 \\
\hline \multicolumn{4}{|l|}{ Complexo Mineral e } \\
\hline Vitaminico * & 0,173 & 0,173 & 0,173 \\
\hline Total & 100,000 & 100,000 & 100,000 \\
\hline
\end{tabular}

* Composição dada na Tabela 7. 
Tabela 5 - Teor em nutrientes das rações experimentais no nĩvel $P_{1}$ de proteina

\begin{tabular}{|c|c|c|c|}
\hline \multirow{2}{*}{ Nutrientes } & \multicolumn{3}{|c|}{ Tratamentos } \\
\hline & $P_{1} O$ & Pיו & $\mathrm{P}_{1} \mathrm{O}_{2}$ \\
\hline Proteina bruta (\%) & 15,13 & 15,03 & 14,92 \\
\hline Fibra bruta $(\%)$ & 10,22 & 9,87 & 9,60 \\
\hline Extrato etéreo (\%) & 4,68 & 7,50 & 10,32 \\
\hline \multicolumn{4}{|l|}{ Extrativos não } \\
\hline nitrogenados $(\%)$ & 61,30 & 58,97 & 56,64 \\
\hline Matēria mineral (\%) & 5,74 & 5,08 & 4,97 \\
\hline Lisina $(\%)$ & 0,62 & 0,62 & 0,63 \\
\hline Metionina + Cistina $(\%)$ & 0,65 & 0,65 & 0,65 \\
\hline Arginina (\%) & 0,85 & 0,84 & 0,84 \\
\hline Energia bruta (Kcal/kg) & 4.1 .05 & 4.235 & 4.365 \\
\hline
\end{tabular}


Tabela 6 - Teor de nutrientes das rações experimentais no nível $P_{2}$ de proteina

\begin{tabular}{lccc}
\hline \multirow{2}{*}{ Nutrientes } & \multicolumn{3}{c}{ Tratamentos } \\
\cline { 2 - 4 } & $\mathrm{P}_{2} \mathrm{O}$ & $\mathrm{P}_{2} \mathrm{O}_{1}$ & $\mathrm{P}_{2} \mathrm{O}_{2}$ \\
\hline Proteina Bruta (\%) & 18,22 & 18,12 & 18,02 \\
Fibra Bruta (\%) & 10,22 & 9,95 & 9,68 \\
Extrato Etéreo (\%) & 4,46 & 7,28 & 10,10 \\
Extrativos não nitrogenados (\%) & 57,98 & 55,65 & 53,32 \\
Matéria Mineral (\%) & 6,17 & 5,41 & 5,30 \\
Lisina (\%) & 0,82 & 0,83 & 0,83 \\
Metionina + Cistina (\%) & 0,78 & 0,78 & 0,78 \\
Arginina (\%) & 1,09 & 1,08 & 1,08 \\
Energia Bruta (Kcal/kg) & 4.123 & 4.253 & 4.383 \\
& & & \\
\hline
\end{tabular}


Tabela 7 - Composição do suplemento mineral e vitaminico e quantidade por quilograma de ração

Composição
Vitamina $A$
Vitamina $\mathrm{D}_{3}$
Vitamina $E$
Vitamina K
Vitamina $\mathrm{B}_{2}$
Vintamina $\mathrm{B}_{12}$
Acido Pontotēnico
Niacina
Colina
Etoxiquim
Manganēs (Mn)
Zinco ( $\mathrm{Zn}$ )
Ferro (Fe)
Cobre (Cu)
Cobalto (Co)
Iôdo (I)
Selênio (Se)

Quantidade

10.000 U.I.

2.000 U.I.

$40 \mathrm{mg}$

$4 \mathrm{mg}$

$5 \mathrm{mg}$

$10 \mathrm{mcg}$

$10 \mathrm{mg}$

$30 \mathrm{mg}$

$200 \mathrm{mg}$

$125 \mathrm{mg}$

$20 \mathrm{mg}$

$40 \mathrm{mg}$

$80 \mathrm{mq}$

$10 \mathrm{mg}$

$0,2 \mathrm{mg}$

$0,6 \mathrm{mg}$

$0,14 \mathrm{mg}$ 


\section{RESULTADOS E DISCUSSAO}

\subsection{Desempenho dos animais.}

Os coelhos no inicio do experimento apresentaram um peso médio de $666,25 \pm 72,44 \mathrm{~g}$ e no final $2.399,06 \pm 214,03 \mathrm{~g}$.

Nas duas primeiras semanas do periodo experimental, o ganho de peso foi baixo, motivado provavelmente à diarréia que acometeu os animais e também ao estresse devido à viagem, mudança de ambiente e manipulações.

As curvas de crescimento podem ser apreciadas na figura 1 , atravēs da qual observa-se o baixo ganho de peso inicial, bem como 0 posterior ganho compensatōrio.

A Tabela 8 mostra os pesos dos animais nos diversos tratamentos. 
31.

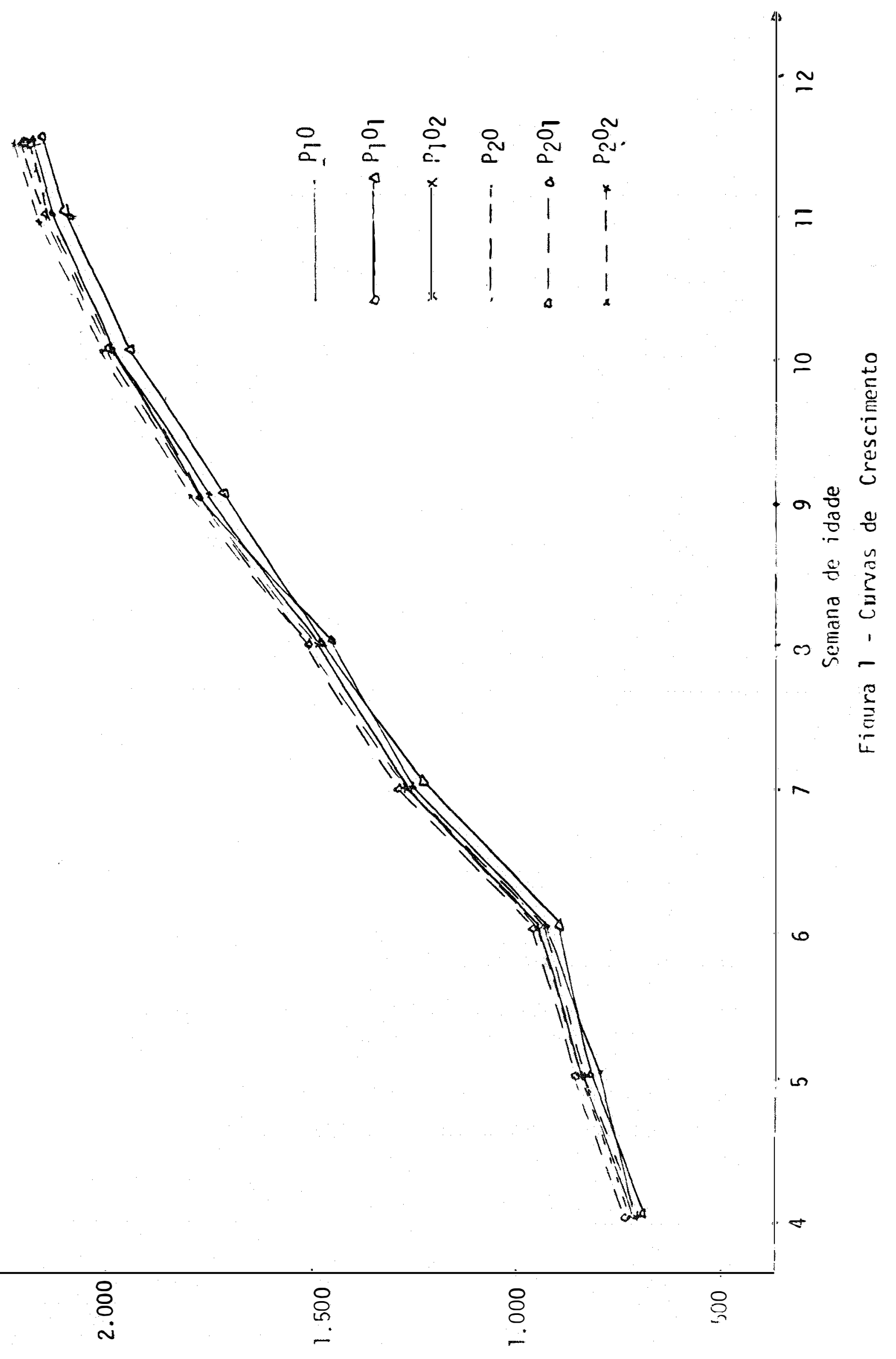


Tabela 8 - Pesos dos animais nos diversos tratamentos expressos em gramas

\begin{tabular}{|c|c|c|c|}
\hline \multirow[b]{2}{*}{ Variāveis } & \multicolumn{3}{|c|}{ Tratamentos } \\
\hline & $\begin{array}{l}P_{1} 0 \\
\bar{x} \pm s \bar{x}\end{array}$ & $\overline{\bar{x}^{\mathrm{P}}{ }_{ \pm}^{0}{ }^{0} \overline{\mathrm{x}}}$ & $\begin{array}{l}P_{102} \\
\bar{x} \pm \mathrm{sx}\end{array}$ \\
\hline Peso inicial & $656,87 \pm 92,46$ & $645,00 \pm 60,47$ & $676,25 \pm 71,55$ \\
\hline Peso final & $2.347,50 \pm 192,91$ & $2.360,00 \pm b 33.73$ & $2.428,75 \pm 164,74$ \\
\hline \multirow[t]{2}{*}{$\begin{array}{l}\text { Ganho de peso } \\
\text { diārio }\end{array}$} & $34,50 \pm 3,36$ & $34,62 \pm 4,08$ & $34,36 \pm 3,06$ \\
\hline & $\mathrm{P}_{2} \mathrm{O}$ & $\mathrm{P}_{2} \mathrm{O}_{1}$ & $\mathrm{P}_{2} \mathrm{O}_{2}$ \\
\hline Peso inicial & $650,00 \pm 85,94$ & $685,00 \pm 72,11$ & $684,37 \pm 59,31$ \\
\hline Peso final & $2.428,75 \pm 164,74$ & $2.433,75 \pm 222,65$ & $2.483,12 \pm 172,04$ \\
\hline $\begin{array}{l}\text { Ganho de peso } \\
\text { diārio }\end{array}$ & $36,30 \pm 3,36$ & $35,68 \pm 3,97$ & $36,71 \pm 3,42$ \\
\hline
\end{tabular}

$\bar{x}=$ média

$s \bar{x}=$ desvio padrão

\subsection{Efeito dos tratamentos sobre o ganho de peso total}

Os resultados do ganho de peso total expresso em gramas, obtidos em cada uma das 48 parcelas experimentais, encontram-se na Tabela $A_{1}$ nio Apēndice.

A Tabela 9 mostra o efeito da proteina e nỉveis de óleo sobre o ganho de peso total por parcela. 
Tabela 9 - Efeitos dos tratamentos sobre o ganho de peso total por parcela expresso em gramas

\begin{tabular}{|c|c|c|c|c|}
\hline \multirow{2}{*}{$\begin{array}{l}\text { Niveis de } \\
\text { proteina }\end{array}$} & \multicolumn{3}{|c|}{ Nĩveis de ōleo } & \multirow{2}{*}{ Mēdia } \\
\hline & 0 & 0 & $\mathrm{O}_{2}$ & \\
\hline$P_{1}$ & $1.690,62$ & $1.696,25$ & $1.683,75$ & $1.690,21$ \\
\hline$P_{2}$ & $1.778,75$ & $1.748,75$ & $1.798,76$ & $1.775,42$ \\
\hline Mēdia & $1.734,68$ & $1.722,50$ & $1.741,25$ & \\
\hline
\end{tabular}

A anālise da variância vista na Tabela 10, revelou a ine xistēncia de efeitos significativos para sexo, proteina, nỉveis de óleo e possiveis interações sobre o ganho de peso total para $(P<0,05)$.

Os efeitos dos tratamentos sobre os ganhos de peso diārios por cabeça são observados na Tabela 11.

\subsubsection{Efeito dos niveis de proteina e aminoäcidos}

0 confronto dos resultados obtidos neste trabalho com a literatura citada, mostra primeiramente concordāncia em ser o nivel de $15 \%$ de proteina, adequado para o crescimento de coelhos na faixa da ida de estudada (N.R.C., 1966; CHEEKE e AMBERG, 1972; DAVIDSON e SPREADBURY, 1973; COLIN, 1973), pois nas oportunidades em que este nivel foi aumenta do não se observou melhora no ganho de peso (COLIN, 1975; LEBAS, 1973 e CHEEKE, 1974). 
Tabela 10 - Análise da variāncia do ganho de peso total

\begin{tabular}{|c|c|c|c|c|}
\hline $\begin{array}{l}\text { Fonte de } \\
\text { variacão }\end{array}$ & G.L. & S.Q. & Q.M. & $F$. \\
\hline Sexo (S) & 1 & $81.263,0208$ & $81.263,0208$ & 2,8146099 n.s. \\
\hline Proteina $(P)$ & 1 & $87.125,5208$ & $87.125,5208$ & 3,0176623 n.s. \\
\hline Oleo (0) & 2 & $2.896,8750$ & $1.448,4375$ & 0,0501678 n.s. \\
\hline$S \times P$ & 1 & 325,5209 & 325,5209 & 0,0011274 n.s. \\
\hline$S \times 0$ & 2 & $163.301,0417$ & $81.640,52085$ & 2,8280312 n.s. \\
\hline$P \times 0$ & 2 & $7.863,5417$ & $3.931,77085$ & 0,1361800 n.s. \\
\hline$S \times P \times 0$ & 2 & $1.426,0416$ & 713,0208 & 0,0246960 n.s. \\
\hline Tratamentos & (11) & $(344.201,5625)$ & & \\
\hline Blocos & 3 & $81.272,3958$ & $27.090,7986$ & 0,93831153 n.s. \\
\hline Resĩduo & 33 & $952.771,3542$ & $28.871,859218$ & \\
\hline Total & 47 & & & \\
\hline
\end{tabular}

Tabela 11 - Efeito dos tratamentos sobre o ganho de peso diārio por cabeça expresso em gramas

\begin{tabular}{ccccc}
\hline $\begin{array}{c}\text { Niveis de } \\
\text { proteĩna }\end{array}$ & \multicolumn{3}{c}{ Niveis de öleo } & \multirow{2}{*}{ Média } \\
\cline { 2 - 4 } $\mathrm{P}_{1}$ & 34,50 & 0 1 & 02 & \\
$\mathrm{P}_{2}$ & 36,30 & 34,62 & 34,36 & 34,49 \\
\hline Mëdia & 35,40 & 35,68 & 36,71 & 36,23 \\
\hline
\end{tabular}


Por outro lado, ficou evidenciado na revisão bibliogrāfi ca a importāncia dos nîveis adequados de alguns aminoácidos para o cres cimento normal de coelhos e apesar da discreta divergência entre os autores quanto a recomendação e resultados obtidos, as informações existentes podem ser consideradas seguras como orientação na pesquisa e for mulações normais.

Com relação à metionina e arginina, por exemplo, observạ se uma concordância muito grande entre os autores e pode-se considerar como adequados os niveis de 0,5 a $0,6 \%$ da ração para metionina e 0,9 a $1,0 \%$ para a arginina.

Considerando-se ganho diārio de peso de $40 \mathrm{~g}$, como média em relação aos obtidos pelos diversos autores, o encontrado neste trabalho situou-se um pouco abaixo e alguns fatores podem ter influenciado nestes valores.

Com relação aos nỉveis de aminoácidos, observa-se que 0 teor de metionina foi adequado tanto para ração com $15 \%$ como para a de $18 \%$ de proteina e, portanto, este aminoácido em particular, provave] mente não tenha influenciado os resultados obtidos. A arginina, por sua vez, apesar te estar presente na ração com $15 \%$ de proteina em nỉvel pou co abaixo do recosnendado, provavelmente também não influenciou o ganho de peso, visto estar com o teor mais elevado na ração com $18 \%$ de prote na, sem contudo observar-se nelhora no ganho de peso.

Por outro, CHEEKE (1971), obteve ganho diārio de $40 \mathrm{~g}$ com $0,88 \%$ de arginina na ração, valor muito prōximo do utilizado neste trabaiho. 
A divergência maior entre os autores refere-se ao teor de lisina, que no presente trabalho, se encontra em quantidades menores às recomendadas pela maioria dos autores, os quais propõem $0,90 \%$ ou mais da ração (CHEEKE, 1978; CHEEKE e AMBERG, 1972; DAVIDSON e SPREADBURY, 1973 e CHEEKE, 1974. Entretanto, COLIN (1973) obteve ganho diārio de $40 \mathrm{~g}$ com 0,78\% de lisina na ração, LEBAS (1973), apesar de trabalhar com nivel de 0,54\%, ainda obteve ganho de $34 \mathrm{~g}$ por dia e, finalmente, COLIN (1974) recomenda $0,65 \%$ do aminoácido na ração, quantidade também proposta por CHEEKE (1977).

Pelos fatos expostos é duvidosa a afirmação de que 0 nivel relativamente baixo de lisina utilizado tenha sido 0 responsāvel pelos resultados obtidos, mormente se considerado que na ração com $18 \%$ de proteina o teor acha-se relativamente mais elevado, sem contudo mostrar resposta proporcional.

Como serā discutido mais adiante, no presente trabalho, obteve baixo consumo de alimento, causado provavelmente pela alta tempe ratura reinante na ocasião. 0 baixo consumo, aliado ou não à quantidade de lisina na ração, pode ter tido uma influência relevante com relação aos dados obtidos.

5.2:2. Égeito da adição de óleo de soja

Os resultados de ARRINGTON et alii (1974), LEBAS (1975) concordam com os do presente ensaio, em que não se verificaram diferenças significativas no ganho de peso em rações com niveis crescentes de óleo. 
A publicação de RAIMONDI et alii (1973), apresenta valores opostos ao acima citados, em que a adição de 3,5\% de ōleo vegetal em rações com 17\% ou 18\% de proteĩna, proporcionaram um menor crescimento, comparando-se com rações idênticas isentas de óleo.

Os estudos de CHIERICATO e LANARI (1972) evidenciaram que a adição em $5 \%$ de sebo bovino, não alterou o ganho de peso.

Somente o ensaio de THACKER (1956) mostra melhoras no ga nho de peso, com o aumento do nível de gordura.

\subsection{Consumo de ração.}

Na Tabela $A_{2}$, no Apéndice, estão os valores do consumo total de ração, expressos em gramas por parcela, durante 0 periodo experimental.

Os efeitos dos tratamentos sobre o consumo total de ração por parcela, são apresentados na Tabela 12.

A Tabela 14 mostra a anālise da variância do consumo total de ração, revelando para $(P<0,05)$ a ausēncia de efeitos significạ tivos para sexo, proteina, nîveis de óleo e possiveis interações.

Na Tabela 13 são mostrados os valores do consumo diārio de ração por cabeça, o qual variou de 52 a $57 \mathrm{~g}$. 0 confronto destes re sultados com os encontrados na literatura consultada, revelaram que no presente trabalho houve um consumo de alimento abaixo do esperado para 
Tabela 12 - Efeito dos tratamentos sobre o consumo total de ração por parcela expresso em gramas

\begin{tabular}{ccccc}
\hline Niveis de & \multicolumn{3}{c}{ Niveis de oleo } & \multirow{2}{*}{ Média } \\
\cline { 2 - 4 } proteina & 0 & $0_{1}$ & $0_{2}$ & \\
\hline$P_{1}$ & $5.342,62$ & $5.060,62$ & $5.098,12$ & $5.168,12$ \\
$P_{2}$ & $5.564,37$ & $5.258,12$ & $5.342,50$ & $5.388,33$ \\
\hline Média & $5.454,99$ & $5.159,37$ & $5.220,31$ & \\
\hline
\end{tabular}

Tabela 13 - Efeito dos tratamentos sobre o consumo diārio de ração por cabeça expresso em gramas

\begin{tabular}{|c|c|c|c|c|}
\hline \multirow{2}{*}{$\begin{array}{l}\text { Niveis de } \\
\text { proteina }\end{array}$} & \multicolumn{3}{|c|}{ Niveis de Oleo } & \multirow{2}{*}{ Mëdia } \\
\hline & 0 & 0 & $\mathrm{O}_{2}$ & \\
\hline$P_{1}$ & 54,54 & 51,64 & 52,02 & 52,73 \\
\hline$P_{2}$ & 56,78 & 53,65 & 54,52 & 54,98 \\
\hline Média & 55,66 & 52,64 & 53,27 & \\
\hline
\end{tabular}


Tabela 14 - Anālise da variāncia do consumo total de ração

\begin{tabular}{lcccc}
$\begin{array}{l}\text { Fonte de } \\
\text { variação }\end{array}$ & G.L. & S.Q. & Q.M. & $F$. \\
\hline Sexo (S) & 1 & $285.955,687500$ & $285.955,687500$ & 1,351794 n.s. \\
Proteĩna $(P)$ & 1 & $581.876,520834$ & $581.876,520834$ & 2,750697 n.s. \\
Oleo (O) & 2 & $779.641,291667$ & $389.820,645834$ & 1,842794 n.s. \\
$S \times P$ & 1 & $6.224,020833$ & $6.224,020833$ & 0,029423 n.s. \\
$S \times 0$ & 2 & $569.853,875000$ & $284.926,937500$ & 1,346931 n.s. \\
$P \times 0$ & 2 & $4.439,291666$ & $2.219,645833$ & 0,010493 n.s. \\
$S \times P \times 0$ & 2 & $139.823,541667$ & $69.911,770834$ & 0,330493 n.s. \\
Tratamentos & $(11)(2.367 .814,229167)$ & - & - \\
Blocos & 3 & $301.210,395834$ & $100.403,465278$ & 0,474636 n.s. \\
Residuo & 33 & $6.980 .749,854166$ & $211.537,874369$ & - \\
\hline Total & 47 & $9.649 .774,479167$ & & \\
\hline
\end{tabular}

$$
\begin{aligned}
\mathrm{CV} & =8,71 \% \\
\text { n.s. } & =\text { Não significativo para }(P<0,05)
\end{aligned}
$$

coelhos nesta faixa de idade. Assim, LEBAS (1973), trabalhando com ra ções em que a proteina oscilou de 11 a $25 \%$, obteve um consumo diārio va riando entre 70 a $110 \mathrm{~g}$. ARRINGTON et alii (1974) empregando animais com sete semanas e rações com 15 e $18 \%$ de proteina, verificou um consumo diārio de 73 a $84 \mathrm{~g}$. COLIN (1974) conseguiu com coelhos entre 42 a 84 dias, atravēs da utilização de rações com 13, 17 e $21 \%$ de proteina um consumo diārio de 78 a $109 \mathrm{~g}$. 
No trabalho de COLIN et alii (1973) ficou evidenciado que um teor de metionina + cistina atē $0,80 \%$ em rações com $17 \%$ de proteî na não alterou o consumo e que todavia, um teor de 1,60\% abaixo o consumo de 73 para $52 \mathrm{~g}$ por dia. Jā no presente experimento supõe-se que o re duzido valor no consumo, não foi provocado pelo teor dos aminoācidos sul furados, que se achavam dentro das normas preconizadas por CHEEKE e AMBERG (1972), ADAMSON e FISHER (1973), CHEEKE (1974) e COLIN (1976a).

A anālise da variāncia do consumo total de ração, evị denciou que à medida que se aumentou o nỉvel energético da ração atravēs da cinclusão do óleo de soja, o consumo não se alterou. Resultados semeIhantes, foram encontrados por RAIMONDI et alii (1973) e LEBAS (1975), concordando com o trabalho de PARIGI-BINI et alii (1974) em que os autores evidenciaram, o não aproveitamento da gordura no trato intestinal de vido aos fenōmenos de saponificação. Jā as pesquisas de ARRINGTON et aiii (1974), CHIERICATO e LANARI (1972) mostraram, que o consumo foi redu zido a adição de gordura.

\subsection{Conversão alimentar}

Na Tabela $A_{3}$, no Apêndice, vê-se a conversão alimen tar expressa em gramas de peso vivo, por parcela.

Os efeitos dos tratamentos sobre a conversão alimentar acham-se na Tabela 15. 
Tabela 15 - Efeito dos tratamentos sobre a conversão alimentar

\begin{tabular}{ccccc}
\hline Niveis de & \multicolumn{3}{c}{ Niveis de Oleo } & \multirow{2}{*}{ Média } \\
\cline { 2 - 4 } proteina & 0 & 01 & 02 & \\
\hline$P_{1}$ & 3,17 & 3,05 & 3,02 & 3,08 \\
$P_{2}$ & 3,00 & 3,13 & 2,97 & 3,03 \\
\hline Média & 3,08 & 3,09 & 2,99 & \\
\hline
\end{tabular}

A anālise da variāncia da conversão alimentar estā discriminada na Tabela 16.

Pôde-se verificar pelos resultados que não houve signifi cância $(P<0,05)$ para sexo, proteina, nîveis de ōleo e possīveis interações.

Observando-se a Tabela 3, nota-se que as rações diferem quanto ao teor de óleo de soja, e em relação aos níveis de proteina e fibra bruta as quantidades permaneceram constantes, graças ao aumento nas proporções do farelo de soja e diminuição das quantidades de farelo de trigo e milho.

Verifica-se, portanto, que foi aumentado o nivel energētico das rações sem al teração nas outras variāveis. Vê-se com os resultados obtidos que não ocorreu modificação na conversão alimentar com o emprego das diferentes formulações. 
Tabela 16 - Anālise da variância da conversão al imentar

\begin{tabular}{lcccc}
\hline $\begin{array}{l}\text { Fonte de } \\
\text { variação }\end{array}$ & G.L. & S.Q. & Q.M. & $F$. \\
\hline Sexo $(S)$ & 1 & 0,0352115 & 0,0352115 & 0,38692859 n.s. \\
Proteina $(P)$ & 1 & 0,0231369 & 0,0231369 & 0,25424444 n.s. \\
Oleo $(0)$ & 2 & 0,0882374 & 0,0441187 & 0,48480713 n.s. \\
$S \times P$ & 1 & 0,0783998 & 0,0783998 & 0,86151184 n.s. \\
$S \times 0$ & 2 & 0,0388511 & 0,01792555 & 0,19697848 n.s. \\
$P \times 0$ & 2 & 0,1289508 & 0,0644754 & 0,70850079 n.s. \\
$S \times P \times 0$ & 2 & 0,0655194 & 0,0327597 & 0,3599865 n.s. \\
Tratamentos & $(11)$ & $(0,4583069)$ & & 1,71648903 n.s. \\
Blocos & 3 & 0,4686148 & 0,15620493 & \\
Residuo & 33 & 3,0030852 & 0,09100258 & \\
\hline Total & 47 & & & \\
\hline
\end{tabular}

$$
\begin{aligned}
\mathrm{CV} & =9,86 \% \\
\text { n.s. } & =\text { Não significativo para }(P<0,05)
\end{aligned}
$$

Com vistas na revisão da literatura encontra-se que 0 aumento no teor de gordura, não modificou a conversão alimentar nos trabaThos de RAIMONDI et alii (1974) e LEBAS (1975). Por outro lado, melho rias na conversão alimentar foram apresentadas por CHIERICATO et alii (1973) e LANARI (1972).

Somente a publicação de THACKER (1956) è que apresenta uma pior conversão alimentar com 0 aumento do teor de gordura da ração. 
43.

6. CONCLUSOES

0 presente ensaio possibilitou as seguintes conclusões:

1. A exigência protéica de coelhos em crescimento pode ser satisfeita com o fornecimento de ração contendo $15 \%$ de proteina bru ta.

2. Os niveis de metionina + cistina e arginina devem estar situados ao redor de 0,65 e $0,84 \%$ da ração com aquele teor protéico.

3. Embora o nivel de $0,62 \%$ de lisina nas rações para coelhos em crescimento com $15 \%$ de proteina bruta tenha sido adequado, supõe-se que deva ser mais elevado.

4. Observou-se que a inclusão de ōleo de soja, em rações para coelhos em crescimento, com 15\% e 18\% de proteĩna bruta, não propiciou um maior ganho de peso e melhoria na conversão alimentar. 
5. O aumento do nĩvel energético das rações a travēs da inclusão do óleo de soja, não alterou o consumo, motivado talvez pela saponificação que ocorre no trato intestinal. 
7. SUMMARY

The objective of the present work was to study the effects of diets with different levels of soybean oil and protein on growth of rabbits.

Ninety-six White New Zealand $x$ California crossed rabbits of both sexes about 30 days old were caged, 2 per cage, during 49 days and fed ad libitum rations with either $15 \%$ or $18 \%$ protein and three different levels of soybean $011,0 \%, 3 \%$ and $6 \%$.

The $15 \%$ protein ration contained $0,62 \%$ lysine, $0,65 \%$ methionine + cystine and 0,84\% arginine; the $18 \%$ protein ration contained respectively, $0,82 \%, 0,78 \%$ and $1,08 \%$ of the same amino acids.

Data were analysed according to a factorial scheme including 2 sexes, 2 protein levels and 3 different levels of soybean oil. Experimental design followed the rondomized blocks model. 
The analysis of variance did not show any significant effect of the different treatments on total weight gain, food conversion and total food consuption.

The following results and conclusions were obtained:

1. The protein needs of growing rabbits can be met by a ration containing $15 \%$ gross protein.

2. At this protein level, the ration must contain from 0,65 to $0,84 \%$ of methionine + cystine.

3. Although the $0,62 \%$ lysine level seemed to be adequate, it is felt that it should be higher.

4. The addition of soybean oil to the experimental rations did not increase either weight gain or food conversion.

5. Also, the addition of soyhean oil did not alter food consumption, probably due to saponification in the gastrointestinal tract. 


\section{LITERATURA CITADA}

ADAMSON, I. e H. FISHER, 1973. Amino acid requirement of the growing rabbit: an estimate of quantitative needs. The journal of Nutrition. Bethesda, 103:1306-1310.

AHLUWALIA, B., G. PINCUS e R.T. HOLMAN, 1967. Essential fatty and its effects upon reproductive organs of male rabbits. The Journal. of Nutrition. Bethesda, 92:205-214.

AITKEN, F.C. e W.K. WILSON, 1962. Al imentaciōn del Conejo para carne $\underline{y}$ peleteria. Trad. Dr. J.A. Escobar, Zaragoza. Editorial Acribia $116 \mathrm{p}$.

A.O.A.C., 1965. Official Methods of Analysis. 10. ed. Washington, Association of Official Agricultural Chemists $957 \mathrm{p}$. ARAGON, T., J. FONOLLA e J. BOZA, 1971. Influence of level of fat on the digestibility of a diet in rabbits. Rivista Española de Fisiologia. 
ARRINGTON, L.R., J.K. PLATT e D. FRANKE, 1974. Fat utilization by rabbits. Journal of Animal Science. Albany, 38:76-80.

CASADY, R.B., R.A. DAMON e A.E. SUITOR, 1961. Effect of supplementary lysine methionine on enteritis mortality, growth and feed efficiency in young rabbits. The Journal of Nutrition. Bethesda, 74:120-124.

CHEEKE, P.R., 1971. Arginine lysine and methionine of the growing rabbits. Nutriton Reports Internationa l. New York, 3:122-128.

CHEEKE, P.R. e J.W. AMBERG, 1972. Protein nutrition of the rabbit. Nutrition Reports International. New York, 4:259-265.

CHEEKE, P.R., 1974. Evaluation of alfafa protein concentrate as a protein source for rabbits. Nutrition Reports International. New York, $\underline{9}: 267-272$.

CHIERICATO, G.M. e D. LANARI, 1972. Contribute sperimentale allo studio dell'influenza della grassatura del mangime e del sesso nella produzione del coniglio da carne. Rivista di Zootecnia. Milano, 3:137-149.

COLIN, M. 1973. Influence de l'addition de lysine a des régimes a base de tourteau de sesame chez le lapin. Journēes de recherches avicoles. et cunicoles. Paris. único:19-21.

COLIN, M., G. ARKHURST e F. LEBAS, 1973. Effects de l'addition de méthionine au régime alimentaire sur les performances de croissance chez le lapin. Annales de Zootechnie. Paris, 22:485-491. 
49.

COLIN, M. 1974. Suplementation en lysine d'un régime a base de tourteau de sésame chez le lapin. Effets sur les performances de croissance et le bilan azoté estimé par deux méthodes. Annales de Zootechnie. Paris, 23: $119-132$.

COLIN, M. 1975. Effets sur la croissance du lapin la supplémentation en L-lysine et en dl-mēthionine de rēgimes vēgētaux simplifiēs. Annales. de Zootechnie. Paris, 24:465-473.

COLIN, M. 1976a. Les besoins en acides aminēs indispensables du lapin en croissance. Ier Congrès International Cunicole, Dijon, 1:17/1-17/4.

COLIN, M. 1976b. Etudes des possibilites de supplēmentation de regimes carencēs par apport le lysine ou de méthionine dans l'eau de boisson chez le lapin. I er Congrès International Cunicole. Dijon, $1: 18 / 1-18 / 4$.

DAVIDSON, J. e D. SPREADBURY, 1973. Ricerche sull'allimentazione del coniglio da carne. Rivista di Zootecnia e Veterinaria. Milano, $6: 611-612$.

LEBAS, F., 1973. Effet de la teneur en protéines de rations a base de soja ou de sésame sur la croissance du lapin. Annales de Zootechnie. Paris, 22:83-92.

LEBAS, F., 1975. Influence de la teneur en enérgie de l'aliment sur les performances de croissance chez le lapin. Annales de Zootechnie. Paris, 24: $281-288$. 
MARTINA, C., 1975. Retete unice de nutreturi combinate pentru ingrasarea intensiva a tineretului cunicul. Lucrarile Stiintifice ale Institutului. de Cercetãri pentree nutritie animalēlor. Bucaresti, 5:169-179.

MARTINA, C., 1976. Formules d'aliments composēs à base de proteine vegetale pour des laperaux à l'engrais. Ier Congrès International Cunicole. Dijon, $1: 23 / 1-23 / 4$.

MAZZIOTTI, Di C.P., R. RAIMONDI, M.T. AUXILIA e G. MASOERO, 1976. Integrazione con metionina e lisina di una dieta per conigli da carne. Annali dell'Instituto Sperimentale per la Zootecnia. Roma, IX no 1:35-46.

MACWARD, G.W., L.B. NICHOLSON e B.R. POULTON, 1967. Requirement of the young rabbit. The Journal of Nutrition. Bethesda, 92:118-120.

NATIONAL RESEARCH COUNCIL, 1954. Committee on animal nutrition. Nutrient requirements for rabbits. Washington, National Academy of Sciences (Nutrient requirement of domestic animal, 9. NAS Publication 331).

NATIONAL RESEARCH COUNCIL, 1966. Sub-committee on rabbit nutrition. Nutrient requirements for rabbits. 2 ed. Washington, National Academy of Sciences (Nutrient requirement of domestic animal, 9. NAS. Publication $1194)$.

PARIGI-BINI, R., G.M. CHIERICATO e D. LANARI, 1974. I mangimi grassati nel coniglio in accrescimento. Rivista di Zootecnia e Veterinaria. Milano, 3:193-202. 
RAIMONDI, R., M. AUXILIA, C. DE MARIA e G. MASOERO, 1973. Effeto comparativo di diete a diverso contenuto energetico e proteico sull' accrescimiento, il consumo alimentare, la resa alla macellazione e le caratteristiche delle carni di coniglio. Convegno Internazionale di Coniglicoltura. Erba, 330-345.

RAIMONDI, R. e M. TEREZA AUXILIA. 1974. Influenza della età allo svezzamento e del livello proteico degli alimenti sull'accrescimento, il consumo alimentare e la resa alla macellazione di conigli all'ingrasso. Annali dell'Istituto Sperimentale per la Zootecnia. Torino, $7(1): 97-112$.

SNEDECOR, G.W. e W.G.COCHRAN. 1975. Metodos Estadisticos. Trad. por J.A. RENOSA FULLER, Ph.D. 6? ed. México, Companhia Editorial Continental, S.A. $703 \mathrm{p}$.

SURDEAU, P., R. HENAFF e G. PERRIER, 1976. Apport et equilibre alimentaire du sodium, du potassium et du chlore chez le lapin en croissance. Ier Congrès International Cunicole. Dijon, $1: 21 / 1-21 / 4$.

TELEKI, M. e A.M. DARWISH, 1970. The effect of dietary fat on energy and protein utilization of rabbits... Nutr. Abstr. Rev. 40:303.

THACKER, E.J., 1956. The dietary fat level in the nutrition of rabbit. The Journal of Nutrition. Bethesda, 58:243-249. 
52.

9. APENDICE 
53.

Tabela $A_{1}$ - Consumo total de ração expresso em gramas por parcela

\begin{tabular}{|c|c|c|c|c|}
\hline Tratamentos & \multicolumn{3}{|c|}{$B / O C O S$} & 4 \\
\hline $\mathrm{P}_{1} \mathrm{O} \quad \mathrm{M}$ & 5.245 & 5.445 & 5.660 & 4.840 \\
\hline PlO F & 5.820 & 5.580 & 4.910 & 5.265 \\
\hline$P_{20} \quad M$ & 4.810 & 5.810 & 5.740 & 5.600 \\
\hline $\mathrm{P}_{2} \mathrm{O} \quad \mathrm{F}$ & 5.315 & 6.365 & 5.605 & 5.270 \\
\hline PI0IM & 5.095 & 5.050 & 5.380 & 5.315 \\
\hline $\mathrm{P}$ & 4.335 & 5.180 & 4.680 & 5.450 \\
\hline$P_{201} M$ & 5.750 & 5.470 & 5.795 & 5.060 \\
\hline $\mathrm{P}_{201 \mathrm{~F}} \mathrm{~F}$ & 4.880 & 4.675 & 5.225 & 5.210 \\
\hline P102 M & 5.840 & 4.680 & 5.375 & 5.155 \\
\hline $\mathrm{PlO}_{2} \mathrm{~F}$ & 5.100 & 5.900 & 4.245 & 4.490 \\
\hline $\mathrm{P}_{2} \mathrm{O}_{2} \mathrm{M}$ & 5.450 & 5.540 & 4.530 & 5.895 \\
\hline $\mathrm{P}_{2} \mathrm{O}_{2} \mathrm{~F}$ & 5.715 & 5.190 & 5.450 & 4.970 \\
\hline
\end{tabular}

$$
\begin{aligned}
& M=\text { Macho } \\
& F=\text { Fêmea }
\end{aligned}
$$


Tabela $A_{2}$ - Ganho de peso total expresso, em gramas, por parcela

\begin{tabular}{|c|c|c|c|c|c|}
\hline \multicolumn{2}{|c|}{ Tratamentos } & \multicolumn{4}{|c|}{ B $10 \mathrm{COS}$} \\
\hline$P_{10}$ & M & 1.375 & 1.770 & 1.775 & 1.705 \\
\hline$P_{10}$ & $F$ & 1.855 & 1.855 & 1.550 & 1.640 \\
\hline$P_{20}$ & M & 1.605 & 1.780 & 1.935 & 1.740 \\
\hline $\mathrm{P}_{20}$ & $F$ & 1.575 & 2.070 & 1.820 & 1.705 \\
\hline P101 & M & 1.695 & 1.775 & 1.995 & 1.795 \\
\hline Pו0ו & $F$ & 1.415 & 1.430 & 1.625 & 1.840 \\
\hline$P_{201}$ & M & 1.995 & 1.865 & 1.990 & 1.610 \\
\hline $\mathrm{P}_{2} \mathrm{OT}^{\circ}$ & $F$ & 1.470 & 1.690 & 1.795 & 1.575 \\
\hline $\mathrm{P} 102$ & M & 1.590 & 1.675 & 1.595 & 2.000 \\
\hline $\mathrm{P} 102$ & $F$ & 1.675 & 1.550 & 1.585 & 1.800 \\
\hline $\mathrm{P}_{2} \mathrm{O}_{2}$ & M & 1.805 & 1.835 & 1.615 & 2.055 \\
\hline $\mathrm{P}_{2} \mathrm{O}_{2}$ & $F$ & 1.945 & 1.575 & 1.670 & 1.890 \\
\hline
\end{tabular}

$$
\begin{aligned}
& M=\text { Macho } \\
& F=\text { Fêmea }
\end{aligned}
$$


Tabela $A_{3}$ - Conversão alimentar, por parcela

\begin{tabular}{|c|c|c|c|c|c|}
\hline \multicolumn{2}{|c|}{ Tratamentos } & \multicolumn{3}{|c|}{$B 10 \mathrm{CO} O \mathrm{~S}$} & \multirow{2}{*}{$\frac{4}{2,84}$} \\
\hline $\mathrm{P}_{1} \mathrm{O}$ & M & 3,81 & 3,07 & 3,18 & \\
\hline P10 & $F$ & 3,14 & 3,01 & 3,16 & 3,21 \\
\hline P2O & M & 3,00 & 2,84 & 2,69 & 2,96 \\
\hline P20 & $\mathrm{F}$ & 3,06 & 3,62 & 2,88 & 2,96 \\
\hline $\mathrm{P}$ POI & M & 3,67 & 2,79 & 3,37 & 2,57 \\
\hline P101 & $F$ & 3,04 & 3,81 & 2,68 & 2,49 \\
\hline $\mathrm{P}_{2} \mathrm{OI}$ & M & 2,99 & 3,26 & 2,96 & 3,22 \\
\hline $\mathrm{P}_{2} \mathrm{O}$ & $F$ & 3,37 & 3,07 & 3,08 & 3,09 \\
\hline $\mathrm{P}_{102}$ & M & 2,88 & 2,93 & 2,91 & 3,14 \\
\hline $\mathrm{P}_{102}$ & $\mathrm{~F}$ & 3,32 & 2,76 & 2,91 & 3,31 \\
\hline $\mathrm{P}_{2} \mathrm{O}_{2}$ & M & 3,02 & 3,02 & 2,80 & 2,87 \\
\hline $\mathrm{P}_{2} \mathrm{O}_{2}$ & $\mathrm{~F}$ & 2,94 & 3,29 & 3,26 & 2,63 \\
\hline
\end{tabular}

$M=$ Macho

F 2 Fèmea 
Tabela $\mathrm{A}_{4}$ - Coeficientes de digestibilidade das rações experimentais

\begin{tabular}{|c|c|c|c|c|c|}
\hline Tratamentos & M.0. & P.B. & E.E. & E.N.N. & F.B. \\
\hline$P_{1} O \quad M$ & 70,39 & 64,28 & 75,09 & 99,64 & 22,87 \\
\hline $\mathrm{P}_{\uparrow} \mathrm{O} \quad \mathrm{F}$ & 70,18 & 65,81 & 75,24 & 77,57 & 33,27 \\
\hline $\mathrm{P}_{1} \mathrm{O}_{1} \mathrm{M}$ & 68,36 & 67,92 & 79,99 & 75,36 & 18,59 \\
\hline $\mathrm{P}_{1} \mathrm{O}_{1} \mathrm{~F}$ & 73,98 & 74,39 & 78,97 & 81,66 & 24,19 \\
\hline $\mathrm{P}_{1} \mathrm{O}_{2} \mathrm{M}$ & 77,21 & 75,36 & 84,37 & 83,44 & 35,73 \\
\hline $\mathrm{P}_{1} \mathrm{O}_{2} \mathrm{~F}$ & 79,28 & 79,63 & 86,39 & 83,92 & 43,71 \\
\hline $\mathrm{P}_{2} \mathrm{O} \quad \mathrm{M}$ & 73,06 & 76,25 & 78,91 & 78,45 & 34,60 \\
\hline $\mathrm{P}_{2} \mathrm{O} \quad \mathrm{F}$ & 75,79 & 77,17 & 82,17 & 81,32 & 37,41 \\
\hline$P_{2} O=M$ & 65,99 & 69,15 & 78,33 & 72,04 & 17,44 \\
\hline$P_{2} O=F$ & 66,48 & 68,23 & 79,81 & 73,29 & 15,54 \\
\hline $\mathrm{P}_{2} \mathrm{O}_{2} \mathrm{M}$ & 80,17 & 80,15 & 91,48 & 84,98 & 41,58 \\
\hline $\mathrm{P}_{2} \mathrm{O}_{2} \mathrm{~F}$ & 74,44 & 77,47 & 87,74 & 78,39 & 32,58 \\
\hline
\end{tabular}

$$
\begin{aligned}
& M=\text { Macho } \\
& F=\text { Fêmea }
\end{aligned}
$$

